\title{
EFEKTIVITAS PERAN AUDITOR INTERNAL DI UIN SYARIF HIDAYATULLAH JAKARTA YANG DITUNJUKKAN OLEH PP NO 60 TAHUN 2008: "SISTEM PENGENDALIAN INTERN PEMERINTAH (SPIP)"
}

\author{
Yusar Sagara \\ UIN Syarif Hidayatullah Jakarta
}

\begin{abstract}
The effectiveness of the Internal Auditor's role in UIN Syarif Hidayatullah Jakarta Shown By Regulation No. 60 of 2008: "Government Internal Control System (SPIP)". This study aims to determine the factors that can create conditions for a good university governance focus more factors that analyzed the role of internal auditors in UIN Syarif Hidayatullah Jakarta. This research was conducted with descriptive method, using research data sources such as government regulation, Regulation, Regulation of the Inspector General, the Statute of UIN Syarif Hidayatullah Jakarta and Regulations Rector. Data collected later dideskriptifkan, analyzed logically, systematic, and consistent with the research paper more detailed and in-depth. Therefore in view of the explanatory data, this research study is referred to as the analytical descriptive. The main finding of this study is that the regulations governing the Internal Control Unit (SPI), especially concerning the role, functions, duties, powers and responsibilities and organizational support is adequate. The findings of the examiner's next is the terminology used by SPI at UIN Syarif Hidayatullah Jakarta is right. Competence of personnel seen backdrop of education is appropriate. Limitations of this study is factor analyzed only on the role of auditors. The author suggests the existence of such advanced research is to expand the knowledge management factors
\end{abstract} Keyword: effectivity of internal audit function, Sistem Pengendalian Intern Pemerintah

Abstrak. Efektifitas Peran Auditor Internal di UIN Syarif Hidayatullah Jakarta yang Ditunjukkan Oleh PP No 60 Tahun 2008: “Sistem Pengendalian Intern Pemerintah (SPIP)". Penelitian ini bertujuan untuk mengetahui faktor-faktor yang dapat membentuk suatu kondisi untuk good university governance yang difokuskan pada peran auditor internal di UIN Syarif Hidayatullah Jakarta. Penelitian ini menggunakan deskriptif, dengan menggunakan sumber data penelitian seperti peraturan pemerintah, peraturan, Peraturan Inspektur Jenderal, Statuta UIN Syarif Hidayatullah Jakarta dan Peraturan Rektor. Data yang dikumpulkan kemudian dideskriptifkan, dianalisis secara logis, sistematis, dan konsisten dengan makalah penelitian yang lebih rinci dan mendalam. Oleh karena itu dalam pandangan data jelas, penelitian ini disebut sebagai deskriptif analitis. Tujuan utama dari studi ini adalah bahwa peraturan yang mengatur Satuan Pengawasan Intern (SPI), terutama mengenai peran, fungsi, tugas, wewenang dan tanggung jawab dan dukungan organisasi memadai. Tujuan berikutnya adalah penggunaan istilah SPI di UIN Syarif Hidayatullah Jakarta yang tepat. Kompetensi personil melihat latar belakang pendidikan yang sesuai. Keterbatasan penelitian ini faktor dianalisis hanya pada peran auditor. Penulis menyarankan adanya penelitian lanjutan tersebut adalah untuk memperluas factor pengetahuan manajemen.

Kata Kunci : Efektifitas peran auditor internal, Sistem Pengendalian Intern Pemerintah 


\section{PENDAHULUAN}

Universitas Islam Negeri (UIN) Syarif Hidayatullah Jakarta selanjutnya disebut UIN Syarif Hidayatullah Jakarta melakukan langkah-langkah strategis sebagai upaya antisipasi realita yang ada yaitu dengan merubah status dan kedudukan menjadi satuan kerja Badan Layanan Umum (BLU) melalui melalui Surat Keputusan Menteri Keuangan Nomor 42/PMK.05/2008 tanggal 26 Februari 2008. Upaya ini dilakukan untuk terus meningkatkan dan menjaga akuntabilitas di bidang pengelolaan keuangan diwujudkan dengan menyusun laporan keuangan BLU UIN Syarif Hidayatullah Jakarta sesuai dengan Standar Akuntansi Keuangan (SAK) per 31 Desember 2008. Hanya dalam waktu 10 bulan UIN Syarif Hidayatullah Jakarta menunjukan kesungguhanya dalam hal akuntabilitas dengan terbitnya laporan keuangan selama 10 bulan. Selain laporan keuangan setahun kemudian tepatnya Januari 2009 BLU UIN Syarif Hidayatullah Jakarta meluncurkan pedoman sistem informasi akuntansi yang ditandatangani rektor dan dijadikan sebagai pedoman berakuntansi di lingkungan BLU UIN Syarif Hidayatullah Jakarta.

Laporan keuangan secara utuh dalam arti 12 bulan berturut-turut telah berhasil disusun yaitu per 31 Desember 2009, 2010, 2011, 2012, 2013 dan 2014. Tidak sampai disitu pada tahun 2011 UIN Syarif Hidayatullah Jakarta menempati peringkat pertama (ke-1) dari 13 Satker Perguruan Tinggi yang sudah berstatus BLU di lingkungan Kementerian Agama berdasarkan Keputusan Direktur Pembinaan Pengelolaan Keuangan Satuan Kerja Badan Layanan Umum Nomor Kepu01/PB.5/2012 tentang Penetapan Hasil Penilaian Kinerja Keuangan Satuan Kerja Badan Layanan Umum tahun 2011, yang diterima pada 30 November 2012 lalu. UIN Syarif Hidayatullah Jakarta mendapatkan total skor 79,87 dengan predikat A (Baik). Skor tersebut didasarkan pada penilaian kinerja keuangan.

Menjadi BLU, total aset tetap UIN Syarif Hidayatullah Jakarta hingga tren 2010 mencapai sekitar Rp 1,2 triliun. Aset tersebut naik dari tahun sebelumnya yang hanya mencapai Rp 1 triliun. Kenaikan penerimaan anggaran yang diperoleh dari pendapatan negara bukan pajak (PNBP) itu dipicu oleh makin membaiknya keuangan sejumlah unit bisnis yang dikelola UIN Syarif Hidayatullah Jakarta selama kurun tiga tahun terakhir. (http://uinjkt.ac.id/index.php/arsip-berita-utama/1696aset-blu-uin-jakarta-capai-rp-1,2-triliun.html). Keberhasilan ini tidak lepas dari peran 
akuntan. Akuntan adalah aktor dibalik tersusunya laporan keuangan UIN Syarif Hidayatullah Jakarta, di dunia manapun laporan keuangan lazimnya adalah 12 bulan, namun terjadi dalam perjalanan sejarah bahwa laporan keuangan BLU UIN Syarif hidayatullah Jakarta untuk yang pertamakalinya terbit hanya dalam waktu 10 bulan.

Selain menempatkan tenaga-tenaga akuntan, pada tahun 2008 UIN Syarif Hidayatullah Jakarta membentuk lembaga pengendali keuangan (LPK) saat ini menjadi Satuan Pemeriksa Intern (SPI) yang tidak lain adalah internal auditnya UIN Syarif Hidayatullah jakarta berdasarkan surat keputusan rektor UIN Syarif Hidayatullah Jakarta Nomor 161 Tahun 2008 yang bertanggungjawab langsung kepada rektor. Selanjutnya berdasarkan SK Rektor UIN Syarif Hidayatullah Jakarta Nomor Un.01/R/HK.005/13/2011 LPK diubah namanya menjadi SPI atau satuan pemeriksa intern sampai saat ini. Selain merubah nomenklatur dan memperkuat status dan kedudukan pada tahun 2011 berdasarkan SK KPA No Un.01/KPA/811/2011 SPI menyusun pedoman pemeriksaan yang sampai saat ini belum dibukukan.

Pada tahun 2008 pemerintah mengeluarkan Peraturan Pemerintah Nomor 60 Tahun 2008 tentang sistem pengendalian intern pemerintah (SPIP) disusul dengan Peraturan Menteri Pendidikan Nasional nomor 16 tahun 2009 tentang satuan pengawasan intern di lingkungan kementerian pendidikan nasioal dan disusul dengan peraturan inspektur jenderal departemen pendidikan nasional nomor kep.275/B/Kp.2009 tentang petunjuk teknis peraturan menteri pendidikan nasional nomor 16 tahun 2009. Walaupun UIN Syarif Hidayatullah Jakarta secara kelembagaan berada di bawah kementerian agama, namun secara akademik UIN Syarif Hidayatullah Jakarta mengacu kepada kementerian pendidikan nasional.

Penelitian ini bertujuan memperoleh bukti empirik (aposteori) terkait dengan peran auditor internal dalam menciptakan tata kelola yang baik di UIN Syarif Hidayatullah Jakarta. Grand theory yang digunakan adalah teori perilaku organisasi. Kegunaan operasional penelitian ini diharapkan dapat memberikan kontribusi dalam kaitanya dengan upaya tata kelola (governance) di UIN Syarif Hidayatullah Jakarta. Diharapkan dengan menerapkan tata kelola yang baik akan mewujudkan good corporate governance dan akhirnya keberlangsungan hidup organisasi akan lestari dan berumur panjang. Modal utamanya adalah kepercayaan dan apabila telah 
tercapai kepeecayaan maka dana akan masuk ke dalam organisasi, sehingga pertumbuhan di sisi keuangan akan tercapai.

Pengawasan merupakan bagian dari fungsi manajemen yang secara khusus mengupayakan rencana yang sudah ditetapkan dapat tercapai sebagaimana mestinya (Sofyan S. Harahap 1992: 77). Pengawasan merupakan bagian dari tata kelola organisasi yang baik, termasuk tata kelola universitas. Konsep pengawasan yang digunakan adalah sebagaimana dimaksud dalam Peraturan Menteri Pendidikan Nasional nomor 16 tahun 2009 tentang satuan pengawasan intern di lingkungan kementerian pendidikan nasioal. Pengawasan adalah seluruh proses kegiatan audit, reviu, evaluasi, pemantauan dan kegiatan pengawasan lain terhadap penyelenggaraan tugas dan fungsi organisasi yang bertujuan untuk mengendalikan kegiatan, mengamankan harta dan aset, terselenggaranya laporan keuangan yang baik, meningkatkan efektivitas dan efisiensi, dan mendeteksi secara dini terjadinya penyimpangan dan ketidakpatuhan terhadap ketentuan peraturan perundangundangan.

Berbeda dengan permendiknas nomor 16 tahun 2009. Dalam Peraturan Pemerintah Nomor 60 Tahun 2008 tentang sistem pengendalian intern pemerintah (SPIP) tidak dipergunakan pengawasan tetapi pengendalian dan dijelaskan bahwa Sistem Pengendalian Intern adalah proses yang integral pada tindakan dan kegiatan yang dilakukan secara terus menerus oleh pimpinan dan seluruh pegawai untuk memberikan keyakinan memadai atas tercapainya tujuan organisasi melalui kegiatan yang efektif dan efisien, keandalan pelaporan keuangan, pengamanan aset negara, dan ketaatan terhadap peraturan perundang-undangan. Pengendalian bertujuan untuk memberikan keyakinan yang memadai bagi tercapainya efektivitas dan efisiensi pencapaian tujuan penyelenggaraan pemerintahan negara, keandalan pelaporan keuangan, pengamanan aset negara, dan ketaatan terhadap peraturan perundang-undangan. Dapat disimpulkan bahwa kata pengendalian dan kata pengawasan sangat berbeda dalam arti penekanan dan tujuan yang hendak dicapai.

Pengawasan merupakan bagian dari fungsi manajemen. Menurut Hani Handoko, pengawasan merupakan proses untuk menjamin bahwa tujuan-tujuan organisasi dan manajemen tercapai. Pengawasan ditekankan pada aspek penetapan 
standar, pengukuran kegiatan dan pengambilan tindakan korektif. Pengawasan yang dimaksud dibagi kedalam lima tahap. Pertama pen etapan standar pelaksanaan yaitu menetapkan suatu satuan pengukuran yang dapat digunakan sebagai patokan untuk penilaian hasil-hasil. Kedua adalah penentuan pengukuran pelaksanaan kegiatan. Ketiga pengukuran pelaksanaan kegiatan, yaitu dengan melakukan pengamatan, pembacaan laporan tertulis dan lisan, metode otomatis dan pengujian/tes Keempat, perbandingan pelaksanaan dengan standar dan analisa penyimpangan, yaitu dengan membandingkan pelaksanaan nyata dengan standar yang telah ditetapkan serta menganalisis penyimpangan yang terjadi (bila ada) teakhir adalah pengambilan tindakan koreksi bila diperlukan dengan cara memperbaiki pelaksanaan, mewngubah standar atau dilakukan perbaikan terhadap keduanya.

Melalui pendekatan kelembagaan, pengawasan diserahkan kepada sebuah lembaga yang berfungsi mengawasi jalanya organisasi agar dapat mencapai tujuan yang telah ditetapkan. Efektifitas pengawasanya bertumpu pada struktur organisasinya. Lembaga pengawas tidak terkait dengan operasional perusahaan. Tidak mungkin seseorang atau lembaga mengawasi pekerjaan yang mereka lakukan sendiri. Tugas pokok operasional dan pengawasan merupakan sesuatu yang berbeda, karenanya harus dipisah. Mengawasi pekerjaan diri sendiri hanya akan membuat penilaian menjadi tidak objektif. Lembaga pengawas juga bersifaf independen dalam arti kerja mereka tidak terikat atau dipengaruhi pihak-pihak lain, baik internal maupun eksternal dengan demikian penilaian diharapkan bersifat objektif sehingga evaluasi dapat dilakukan untuk perubahan ke arah yang lebih baik.

Melihat kompleksitasnya permasalahan operasional organisasi dan tantangan yang ada, orang-orang yang duduk di lembaga pengawas juga hendaknya memiliki keahlian yang lengkap, setidaknya melebihipihak yang diawasi. Terakhir yang paling penting adalah lembaga pengawas harus memenuhi kriteria integritas dan kejujuran. Tanpa kejujuran proses pengawasan tidak akan dipercaya orang. Dan akhirnya pengawasan tidak akan efektif. Melalui pendekatan sistem, pengawasan dilakukan melalui pewngaturan sebuah prosedur dan hubungan antar subsistem di organisasi tersebut agar tidak terjadi penyimpangan dari tujuan organisasi. Pendekatan sistem melahirkan pengawasan internal 
Drucker (45:1974) menyatakan bahwa efektivitas adalah mengajarkan sesuatu hal yang benar ("doing the right things"). Cameron (539:1986) bahwa efektivitas adalah sebuah paradoks dimana tidak ada organisasi pun bisa memenuhi semua elemen efektivitas. Sofyan Safri Harahap menyatakan bahwa pengawasan yang efektif apabila :

1. Posisi jabatan pengawasan itu benar-benar independen dalam arti tidak tergantung kepada siapa yang diawasi dan pekerjaan apa yang diawasi

2. Posisi jabatan pengawasan itu harus berada di posisi/jabatan yang diawasi

3. Harus ada prosedur dan manual yang baku, tertulis dan teruji sebagai dasar (ukuran) bagi pengawas untuk melaksanakan pengawasan

4. Pengawas harus memiliki kualitas kejujuran yang tinggi

5. Pegawas harus memiliki pengetahuan teori dan keterampilan yang luas Committe of sponsoring organizations of the teadway commission (COSO), Amerika serikat mengidentifikasi tujuh prinsip yang terkai dengan lingkungan pengawasan yang efektif (efektive control enviroment) yang bwerujung pada laporan keuangan yang baik. Ketujuh prinsip tersebut adalah

1. Integritas dan nilai-nilai etika yang dikembangkan, dipahami dan dilaksanakan oleh segenap pegawai, terutama manajemen puncak

2. Dewan direksi memahami dan melaksanakan tanggungjawab pengawasan terkait dengan pelaporan keuangandan pengendalian internal

3. Memiliki filosofi manajemen dan gaya operasi yang mendukung tercapainya pengendalian internal yang efektif terhadap pelaporan keuangan

4. Struktur organisasi perusahaan yang jelas dengan garis komando dan koordinasi yang jelas

5. Kompetensi indivisu, indivudu yang bekerja di organisasi harus ditempatkan sesuai kompetensi dan keahlian yang dimilikinya agar pengawasan tewrjadi secara efektif

6. Wewenang dan tanggungjawab. Manajemen dan karyawan di tempatkan pada tingkat yang sesuai dengan wewenang dan tanggungjawabnya untuk memfasilitasi pengendalian internal yang efektif terhadap pelaporan keuangan 
7. Kebijakan sumbewr daya manusia dan praktek yang dirancang untuk memfasilitasi pengendalian internal yang efektif terhadap pelaporan kewuangan

Efektivitas peran auditor internal dikukur berdasarkan dengan mengakui sumberdaya dan proses yang mempengaruhi tujuan pengawasan yang menjadi tugas pokok SPI. SPI dikatakan efektif apabila mereka dapat bekerja sesuai dengan tugas pokoknya, yaitu menjalankan pengawasan tempat di mana mereka bekerja.

Tugas auditor internal dalam perusahaan bertujuan untuk menilai efisiensi dan efektifitas kegiatan usaha dan juga pengendalian internal, seperti yang dinyatakan oleh (Mulyadi,2002:29): "Auditor intern adalah auditor yang bekerja dalam perusahaan (perusahaan Negara maupun swasta) yang tugas pokoknya adalah menentukan apakah kebijakan dan prosedur yang ditetapkan oleh manajemen puncak telah dipatuhi, menentukan baik atau tidaknya penjagaan terhadap kekayaan organisasi, menentukan efisiensi dan efektifitas prosedur kegiatan organisasi serta menentukan keandalan informasi yang dihasilkan oleh berbagai bagian organsiasi".

Tujuan dari audit internal menurut (Hiro Tugiman, 1997:99) adalah: "Tujuan pelaksanaan audit internal adalah membantu para anggota organisasi agar mereka dapat melaksanakan tanggung jawabnya secara efektif. Tujuan audit internal mencakup pula usaha mengembangkan pengendalian yang efektif dengan biaya yang wajar". Dengan katalain tujuan audit internal memberi pelayanan kepada organisasi untuk membantu semua anggota organisasi tersebut. Bantuan yang diberikan sebagai tujuan akhir adalah agar semua anggota organsisasi dapat melakukan tanggung jawab yang diberikan dan dibebankan kepadanya secara efektif. Audit internal membantu manajemen dalam mencarikemungkinan yang paling baik dalam hal penggunaan sumber modal secara efisien danefektif. Semua bantuan audit internal dapat diberikan melalui analisis-analisis, penilaian,saran, bimbingan serta infornasi tentang aktivitas yang diperiksa. Bagian internal audit ini merupakan bagian yang terkait dalam Satuan Pengawasan Intern perusahaan

Praktek tata kelola yang baik pertama kalinya diterapkan di perusahaan. Tata kelola perusahaan (CG, corporate governance) adalah topik yang mendapatkan perhatian besar, baik, dari para ilmuwan maupum lembaga otoritatif. Fenomena tata kelola perusahaan telah muncul dari struktur dan peristiwa ekonomi dan organisasi, 
termasuk meningkatnya pemisahan kepemilikan dan kontrol, deregulasi, globaisasi, skandal dan bangkrutnya perusahaan, krisis ekonomi Asia, dan munculnya aktivisme pemegang saham.

Definisi otoritatif CG pertama kali diformulasikan oleh The Organisation for Economic Co-operation and Development (OECD). Definisi ini menerapkan sebuah penekanan hubungan pada tata kelola perusahaan sebagai "hubungan penuh antara manajemen perusahaan, dewan pengawas, pemegang saham, dan pihak-pihak terkait. OECD menjelaskan bahwa definisi ini menyediakan struktur yang mengatur dan memonitor tujuan perusahaan.

Definisi CG dijumpai dalam berbagai disiplin ilmu dengan berbagai pendekatan, seperti ekonomi, psikologi, filsafat, maupun agama. Definisi dalam Cadbury Report merupakan salah satu definisi yang digunakan secara luas, di mana tata kelola perusahaan secara sederhana dan mendasar diartikan sebagai "suatu sistem untuk mengarahkan dan mengendalikan perusahaan.

CG merupakan suatu sistem yang mengatur hak, proses dan kendali yang dibangun manajemen suatu entitas bisnis baik secara internal maupun eksternal. Umumnya CG meliputi prosedur untuk mengarahkan dan mengawwasi organisasi, proses pembuatan keputusan perusahaan, membuka informasi entitas keuangan dan operasi, dan kerangka kerja untuk meminotor kinerja manajemen.

Tidak ada definisi tunggal untuk CG. Secara prinsip, CG merupakan seperangkat aturan yang merumuskan hubungan antara pemegang saham, manajer, kreditorr, pemerintah, karyawan, dan pihak-pihak lain yang berkepentingan baik internal maupun eksternal sehubungan dengan hak-hak dan tanggung jawab mereka . CG mengatur peran dan fungsi lembaga pengawas perusahaan yang mengacu kepada strategi perusahaan atau keputusan manajemen, serta hak dan kewajiban pemegang saham.

Kajian dan penelitian akademik terkait CG bervariasi dari berbagai aspek, mulai dari definisi, struktur, dan mekanisme pengawasan. Seiring dengan meningkatnya jumlah perusahaan yang ambruk dalam beberapa tahun terakhir, penerbitan aturan dan penelitian akademik untuk meningkatkan mekanisme tata kelola perusahaan terus meningkat. Di antara mekanisme pengawasan yang banyak dibahas adalah independensi badan pengawas dan komite audit. 
Penelitian Manu Gupta menunjukkan bahwa para investor mempertimbangkan independensi pengawas (board independence) sebagai sebuah aspek penting dalam CG. Sementara McCabe meneliti persepsi direktur perusahaan di Australia terhadap praktek terbaik (best practice) tata kelola perusahaan. Dia memberikan deskripsi tentang definisi dan praktek terbaik tata kelola perusahaan.

Penelitian terkait dengan hubungan antara struktur tata kelola perusahaan dengan performa organisasi umumnya terfokus pada efek holistik beragam konfigurasi tata kelola terhadap performa. Kajian terhadap struktur badan pengawas banyak terfokus pada kepemimpinan, komposisi, dan jumlah anggota.

\section{METODOLOGI}

\section{1) Objek Penelitian}

Yang menjadi objek penelitian adalah peran internal auditor. Subjek penelitian ini adalah SPI UIN Syarif Hidayatullah Jakarta. Menurut Suharsimi Arikunto (2006) menjelaskan bahwa variabel adalah objek penelitian atau apa yang menjadi titik perhatian dari suatu penelitian, sedangkan tempat di mana objek melekat merupakan subjek penelitian.

\section{2) Metode Penelitian}

Tipe penelitian ini adalah deskriptive research. Menurut Kothari (37:2004) penelitian deskriptif adalah penelitian yang terkait dengan uraian dan karakteristik suatu individu atau sebuah kelompok tertentu. Penelitian deskriptif bertujuan untuk mengetahui keadaan atau status tertentu dan berusaha menggambarkan fenomena tersebut. Dalam penelitian bisnis disebut Ex post facto research di mana ciri utama metode ini adalah peneliti tidak melakukan kontrol atas variabel-variabel yang diteliti, melainkan hanya melaporkan apa yang terjadi.

\section{3) Sumber, Teknik Pengumpulan dan Analisis Data}

Sumber utama data dalam penelitian ini adalah bahan pustaka berupa Undang-undang Keuangan Negara, Peraturan Pemerintah, Peraturan Menteri, Peraturan Inspektorat Jenderal, Statuta UIN Syarif Hidayatullah Jakarta dan Peraturan Rektor.

Data yang terkumpul kemudian dideskriptifkan, dianalisis secara logis, siostematis, dan konsisten dengan telaahan yang lebih rinci dan mendalam. 
Karenanya di lihat dari eksplanasi datanya, penelitian ini disebut sebagai penelitian yang bersifat desktiftif analitis.

\section{PEMBAHASAN}

"De waarheid ligt in het midden" (="kebenaran berada di tengah-tengah). Tulisan ini terinspirasi oleh ucapan Shakespeare "What's in a name ? That which we call a rose by any other word would smell as sweet". Oleh penulis, kalimat kedua dirubah tanpa merubah makna nya yaitu dengan : "You give a rose another name, it's quite the same". Kalimat yang ditulis oleh seorang murid kepada gurunya yaitu Prof. Soemarjo pada tahun 1984. Tulisan ini penulis kutip dari buku yang diterbitkan FE UI tahun 1984 berupa kumpulan karangan Prof. Dr. S. Hadibroto yang tidak lain ayahanda Ahmadi Hadibroto pelanjut sekaligus akuntan Indonesia yang berhasil menjadikan profesi akuntan Indonesia setara dengan akuntan asing. Tradisi saling menanggapi suatu ide atau gagasan lazimnya selalu terjadi dalam dunia keilmuan. Begitupula yang terjadi pada penulis saat masih berada dalam binaan sang guru. Penulis kerap melontarkan ide atau gagasan yang saling tanggap antara guru dan murid. Saat ini setelah sang murid yang sudah tidak dibawah binaan sang guru ide dan gagasan itu muncul kembali hadir dalam bentuk karya yang lebih formal. Menulis bagi saya adalah pengobat rindu sekaligus mempertemukan dan mendialogkan ideologi yang tiba-tiba saja muncul.

Keberadaan Satuan Pengawas Intern (SPI) UIN Syarif Hidayatullah Jakarta mengacu kepada Peraturan Menteri Agama Republik Indonesia Nomor 17 Tahun 2014 Tentang Statuta UIN Syarif Hidayatullah Jakarta. Bab 1 pasal 1 angka 9 menyebutkan Satuan Pemeriksa Intern (SPI) adalah pemeriksa internal Pengelolaan Keuangan Badan Layanan Umum (PK-BLU) Universitas. Terminologi yang digunakan adalah pemeriksa bukan pengendali atau pengawas. Analogi penulis adalah seorang dokter yang memeriksa pasien, bukan dokter yang mengendalikan atau mengawasi pasien. Dokter adalah orang lain yang memiliki ilmu kedokteran yang dibayar jasanya untuk memeriksa kesehatan pasien. Hal ini bisa dipahami dengan definisi internal auditing yaitu pekerjaan penilaian yang bebas (independen) di dalam suatu organisasi untuk meninjau kegiatan-kegiatan perusahaan guna memenuhi kebutuhan pimpinan. Jika analogi penulis benar maka terminologi pemeriksaan sudah tepat digunakan untuk menjaga independensi. Seorang dokter akan memeriksa secara 
bebas, melakukan analisa dan menarik kesimpulan serta merekomendasikan tindakan perbaikan. Untuk menjaga independensi maka SPI UIN Syarif Hidayatullah Jakarta menggunakan terminologi ini. Namun apakah auditor internal sama dengan dokter. Tentunya tidak sama.

Penjelasan tentang pemakaian istilah "pengendalian" dan "pengawasan" Misalnya, Drs. Gandhi menulis bahwa "Pengawasan berhenti setelah mengkonstatir dan memberitahukan sedangkan pengendalian melanjutkan dengan tindakantindakan. Departemen P.U. mendifinisikan pengendalian sebagai fungsi yang mengatur dan mengarahkan cara pelaksanaan dari suatu rencana program, proyek dan kegiatan di samping fungsi management lainnya. Apakah ini sebenarnya bukan fungsi management sendiri dalam echelon bawah, sehingga justru istilah kontrol tidak tepat, karena dalam echelon bawah (manager bawahan) manager mempunyai fungsi directing (mengatur) dan organizing (pengaturan tata laksana) yang tak tepatlah untuk diindentikkan dengan 'controlling". Departemen P.U. dalam definisinya mengenai pengawasan yang berbunyi, bahwa "pengawasan adalah fungsi yang di satu pihak menjaga dan mengusahakan ketaatan terhadap penerapan dari tata laksana yang berlaku. Lebih lekat dengan pengertian "pengawasan intern" (= internal control).

Direktorat Jenderal Pengawasan Keuangan Negara merumuskan kaitan pengawasan dan pengendalian sebagai berikut Suatu usaha untuk membandingkan apakah yang telah dilakukan sesuai dengan rencana. Pengertian internal control memang bukan pengertian aktivitas, melainkan pengertian kondisi, sarana atau system, jadi merupakan pengertian "software" dan bukan pengertian aktivitas atau tindakan. Dengan definisi ini, maka pengendalian, pemeriksaan dan pengawasan intern dan sebagainya merupakan unsur pengawasan. Memang kadang-kadang pengawasan disalin dengan supervisi, tetapi ini adalah akibat kenyataan, bahwa supervisi memang termasuk dalam pengertian pengawasan sesuai dengan definisi tersebut, atau pengawasan dalam arti sempit. Jelaslah, bahwa tergantung dari bagaimana istilah tersebut didefinisikan akan ditentukanlah pula pemakaian istilah "pengawasan" atau "pengendalian"

SPI pusat atau lembaga. Sesuai dengan statuta UIN Syarif Hidayatullah Jakarta, SPI dipimpin oleh seorang kepala bukan ketua. Selanjutnya terminologi kepala 
menunjuk kepada kepala pusat. Dan yang dimaksud dengan kepala pusat adalah pimpinan pusat pada univeritas. SPI berada di bawah rektor dan bertanggungjawab kepada rektor. SPI wajib menyampaikan laporan tahunan berupa temuan, rekomendasi dan tindak lanjut hasil temuan kepada rektor. Perlu diketahui bahwa laporan SPI kepada rektor bukan laporan kinerja keuangan dan kinerja administrasi namun SPI haru dapat menyampaikan laporan temuan, tindak lanjut temuan serta menilai risiko-risiko yang dihadapi.

Setiap tahun sebelum memulai penugasan SPI UIN Syarif Hidayatullah Jakarta perlu dilengkapi dengan SPI Charter yaitu piagam SPI yang berisi kesepakatan atau kontrak antara SPI, Rektor dan objek yang akan diaudit. SPI ini berisi kewenangan yang boleh dan yang tidak boleh atas apa-apa yang dikerjakan atau tidak dikerjakan. Selasin SPI Charter juga dilengkapi dengan pedoman pemeriksaan yang standar. Pedoman pemeriksaan ini sebagai suatu acuan SPI dalam praktik pemeriksaan, dalam rangka menjaga kompetensi dan keahlian serta meningkatkan keterampilan dan pemahaman serta pengetahuan personel SPI perlu dilengkapi dengan pendidikan dan pelatihan secara terstruktur agar dapat menjaga kompetensinya sebagai auditor internal. Diklat dengan jam khusus perlu diikuti oleh internal auditor sebagai bukti bahwa mereka berkecukupan dalam kompetensinya

\section{KESIMPULAN}

Untuk dapat memerankan auditor intern sebagai assurance maka metode audit harus dirubah dari post audit menjadi current audit. Peran baru pengendalian internal yaitu consulting bukan pemeriksa perlu dilakukan. Implementasi on going audit yang sesuai dengan peran baru pengendalian intern sebagai consulting adalah dengan menempatkan auditor pada satu obyek pemeriksaan (person in charge) sebagai konsultan dengan tugas melakukan pendampingan terhadap program/kegiatan yang sedang berjalan pada suatu obyek pemeriksaan, namun auditor tersebut tidak harus menetap secara terus menerus pada obyek pemeriksaan tersebut. Auditor dapat datang secara berkala atau sewaktu-waktu apabila terdapat permasalahan yang mana waktu kedatangan dan jumlah frekuensi kunjungan dapat diatur sesuai dengan kebutuhan. Di luar kunjungan tersebut antara auditor dan auditan dapat menjalin komunikasi. 
Disamping itu terkait dengan pelaksanaan peran assurance, maka mau tidak mau SPI UIN Syarif Hidayatullah Jakarta harus sudah mulai menerapkan audit berbasis risiko (risk base audit). Namun sebelum menerapkan pendekatan audit ini, maka terlabih dahulu unit kerja di lingkungan UIN Syarif Hidayatullah Jakarta melakukan pengelolaan risiko (risk management) sesuai dengan Peraturan Pemerintah no.60 tahun 2008 tentang SPIP. Idealnya disetiap unit kerja terdapat unit kerja yang diberikan tanggung jawab untuk mengelola risiko ini.

Dengan adanya Satuan pemeriksa Internal (SPI) disetiap unit kerja, maka SPI ini ini dapat diarahkan untuk mengelola risiko tersebut. Untuk tahap awal, akuntan yang ada di uint kerja dapat membantu SPI disetiap unit kerja dalam mengelola risiko, selanjutnya auditor intern menguji atau mengetes kembali kecukupan dan keandalan pengendalian yang dibuat manajemen melalui aktivitas audit, reviu, dan evaluasi, selanjutnya apabila pengendalian yang dibuat manajemen tidak cukup dan tidak memadai maka auditor intern memberikan rekomendasi perbaikan.

Untuk dapat memerankan peran assurance maka auditor SPI UIN Syarif Hidayatullah Jakarta harus selalu meningkatkan kompetensinya baik pengetahuan, ketrampilan dan sikap melalui peningkatan kualifikasi pendidikan, pelatihanpelatihan maupun sertifikasi-sertifikasi keahlian yang diperlukan sebagai auditor intern yang diimbangi dengan pembinaan yang dilakukan secara adil dan konsisten.

\section{REFERENSI}

Drucker, P. F. Tasks, responsibilities, practices. New York, NY: Harper \& Row, 45, 1974.

Hadibroto, Suhadji (1987) Masalah Akuntansi,FEUI, Jakarta

Handoko, T. Hani (1999) Dasar Dasar Manajemen, BPFE, Yogyakarta

Harahap, Sofyan S (1992) Akuntansi, Pengawasan, Manajemen dalam Pewrspektif Islam, FE Trisakti, Jakarta

Keputusan Menteri Keuangan Nomor 42/PMK.05/2008 Tentang Pembentukan Satuan Kerja Badan Layanan Umum UIN Syarif Hidayatullah Jakarta

Kothari, C.R. 2004. Research Methodology Methods and Techniques. Second Revised Edition. New Delhi: New Age International Publishers.

Kumaat, Valery G. 2011. Internal Audit. Jakarta: Erlangga.

Mulyadi. 2002. Auditing. Buku dua, edisi ke-6. Salemba Empat. Jakarta. 
Peraturan Inspektur Jenderal Departemen Pendidikan Nasional Nomor KEP.275/B/Kp.2009 Tentang Petunjuk Teknis Peraturan Menteri Pendidikan Nasional Nomor 16 Tahun 2009 Tentang Satuan Pengawasan Intern di Lingkungan Kementerian Pendidikan Nasional

Peraturan Menteri Agama Republik Indonesia Nomor 17 Tahun 2014 Tentang Statuta UIN Syarif Hidayatullah Jakarta

Peraturan Pemerintah No. 74 Tahun 2012, tentang Perubahan atas Peraturan Pemerintah No. 23 Tahun 2005 Tentang Pengelolaan Keuangan Badan Layanan Umum

Peraturan Pemerintah Republik Indonesia, No. 60 tahun 2008, tentang "Sistem Pengendalian Internal Pemerintah (SPIP)".

Peraturan Pemerintah Republik Indonesia, No. 71 tahun 2010, tentang "Standar Akuntansi Pemerintahan (SAP)".

SK KPA No Un.01/KPA/811/2011 Tentang Penyusunan Pedoman Pemeriksaan SPI UIN Syarif Hidayatullah Jakarta

SK Rektor UIN Syarif Hidayatullah Jakarta Nomor 161 Tahun 2008 Tentang Pembentukan Lembaga Pengendali Keuangan

SK Rektor UIN Syarif Hidayatullah Jakarta Nomor Un.01/R/HK.005/13/2011 Tentang

Perubahan Nomenklatur Lembaga Pengendali Keuangan Menjadi Satuan Pemeriksa Intern

Soewardi, Herman 1999. Roda Berputar Dunia Bergulir : Kognisi Baru Tentang Timbul Tenggelamnya Sivilisasi. Bandung : Bakti Mandiri

Suharsimi, Arikunto, 2006. Prosedur Penelitian Suatu Pendekatan Praktik. Jakarta : Rineka Cipta.

Tugiman, Hiro. 1997. Standar Profesional Audit Internal. Penerbit Kanisius. Yogyakarta.

Website

http://www.uinjkt.ac.id/index.php/arsip-berita-utama/2360-blu-uin-jakarta-raihnilai-a.html

http://uinjkt.ac.id/index.php/arsip-berita-utama/1696-aset-blu-uin-jakarta-capairp-1,2-triliun.html 